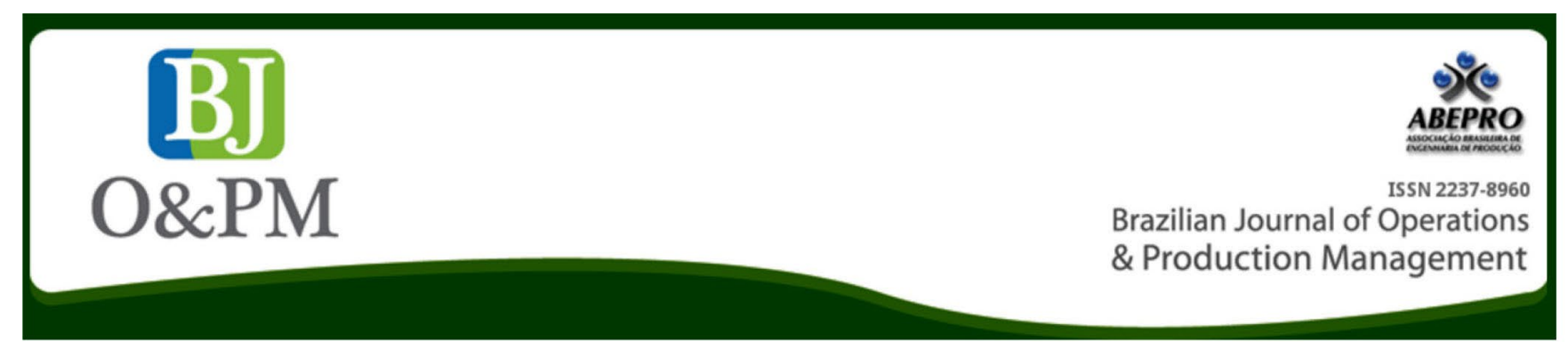

\title{
THE CONTRIBUTION OF ERGONOMICS TO THE EFFECTIVENESS OF THE PUBLIC SERVICE: ANALYSIS OF THE IMPLEMENTATION OF THE ELECTRONIC JUDICIAL PROCESS (PJE)
}

Ivany Rocha Yparraguirre elaine_fragoso@id.uff.br Fluminense Federal University, Niterói, Rio de Janeiro, Brazil.

\begin{abstract}
The Brazilian Justice, propelled by the benefits that the technological era can bring to the speed of the jurisdictional provision, proposed the implementation of the Electronic Judicial Process (PJe). In this context of demand for effectiveness, this article aims to identify and evaluate comparatively the ergonomics practices versus the recommendations of the theory on the search of the effectiveness of the Brazilian public service. The analysis focuses on the implantation of the PJe in the Brazilian Courts of Justice and the repercussions on the Quality of Work Life, identifying opportunities for the improvement of the results through the development and application of Ergonomics. The methodological strategy included a review of the literature, field observation, unstructured interviews, document analysis and comparative evaluation of theoretical models and practices in the implantation of the PJe. The results obtained were constituted by a chart illustrating the comparison between practices identified in the implantation of the PC and the possible opportunities of Light Improvements of the literature in Ergonomics. It could be observed that, after almost 10 years since the publication of Law 11,419 / 2006, which defined the implantation of the PJe in the Brazilian Judiciary, there are still few studies that consider and implement care regarding the ergonomic risks and the health and safety of the servers.
\end{abstract}

Keywords: PJe; Electronic Judicial Process; ergonomic risks in Computerized Work; Risks to Occupational Safety and; Health and Quality of Life at Work. 
Brazilian Journal of Operations \& Production Management

Volume 15, Número 1, 2018, pp. 127-136

DOI: 10.14488/BJOPM.2018.v15.n1.a11

\section{SITUATION PROBLEM}

Rothberg (2010) describes conclusions from research on the theory of digital democracy as a support for the formulation of public policies. In the Brazilian federal government, online public consultations have gained space as a means of formulating shared public policies of various sectors of the government. Despite the rapid diffusion of these instruments of political participation, there is resistance to their implementation.

Moura (2014) presents an account of the electronic process in the labor judiciary as an inducer of the effectiveness of the jurisdictional provision: access to justice observed in a broader way, considering the effectiveness of the jurisdictional provision and its speed. It also evaluates the paradigm shift, as a function of the new electronic procedure for processing processes.

Carvalho (2015) reports and analyzes the suffering of work in the Brazilian judiciary. According to the author, work must be understood as a mediating activity between the construction of subjectivities and the social field, in a historical relation between individuality and collectivity. Under the "spirit of toyotism" in the complex, arising from productive restructuring, labor relations are linked to the increase of productivity. The author's account elucidates this complex metabolism between work, ideology and subjectivity, taking into account the particularities of labor relations in the public sphere.

Tavares (2003) describes and analyzes the social representation of suffering in the group work of servants of a Federal Judicial Court. The social representation of suffering was organized in three groups of meaning: 1) Constitutive elements: injustice in the work environment, cumulative volume of work, non-recognition of work, lack of autonomy, professional stagnation, and oppression by superiors; 2) Moderating elements: explicit criteria for granting gratifications, positive social relations in the workplace, learning at work, adequate management of workload by managers, coping strategies (affective distancing of the causes of the processes, disengagement with work, search for other opportunities within the institution through personal contacts, study to enter legal careers such as magistracy, invest affectively and intellectually in dimensions of extra-work life); 3) Expressions of suffering: fear, feeling of self-devaluation, hopelessness and discouragement, contamination of thought and sleep by work contents, somato-psychological illnesses. The results presented by the author show that the categories of suffering at work are related to the frustration of the human needs and the professional expectations of the servants. Emphasis is given to the importance of knowledge in terms of health promotion actions at work in modern- ization projects and search for effectiveness in the results of the services provided.

Bezerra (2014) reports research in the scope of the Ergonomics of Applied Activity to Quality of Life at Work. Data analysis showed that workers relate QLW with the following factors: Harmonious socio-professional work relationships; appropriate working conditions; effective organization of work; recognition and professional growth and; link between work and social life. The research identified the main factors that interfere in the representations of well-being and malaise of the sample of 37 workers from different areas and functional links of the public institution.

Ferreira et al. (2009) present a research result in which the emphasis is on the Quality of Work at Work (QWL). The programs that QWL practices in the Brazilian public bodies remain underdeveloped. The results show that the practices of QWL in the Brazilian public service are characterized by a clear mismatch between existing problems and activities carried out, with a QWL approach of assistentialist bias. The relationship between Activity Ergonomics and the thematic field of QWL can be better understood in Ferreira (2008). The analysis and interpretation of the results of this research are based on the Ergonomics of Activity approach, according to Guérin et al. (2001). This discipline can be conceptualized as an anthropocentric scientific approach that is based on interdisciplinary knowledge of the human sciences to make products and technologies compatible with the characteristics of the users and to humanize the socio-technical context of work, analyzing the subject's objectives and / or effectiveness of the results.

Costa Júnior (2015) describes the achievements of the Electronic Judicial Process (PJe), specifically in Labor Justice. $\mathrm{He}$ analyzes the existing challenges and contrasts benefits with the State's commitment to guarantee access to justice. Considering the context and the problem situation, the research questions can be presented:

What is the contribution of ergonomics to the effectiveness of the public service, in the case of the implementation of the Electronic Judicial Process (PJe)? Due to the demand for innovation in the operation of public services, what do the scientific and technical literatures reflect, analyze and propose regarding the implementation of the Electronic Judicial Process (PJe) in the Brazilian Courts of Justice and what are the repercussions on the quality of life, specifically health and security of the servers of these institutions?

Depending on the context, the problem situation and the research questions described, the research objectives are defined: This study has the purpose of comparing the ergonomics practices and the recommendations of the theory about the search for the effectiveness of the Brazilian pub- 
lic service, as a function of the implementation of operating systems that aim at the effectiveness of the results in the provision of services to the public.

The analysis of this study focuses on the implantation of the PJe in the Brazilian Courts of Justice and its repercussions on the Quality of Life of the Work, specifically on the health of the workers, additionally identifying opportunities of improvements in the effectiveness of the results through the development of the application of Ergonomics.

A review of the literature on related issues was also carried out in order to contextualize the topic addressed:

- Implementation of the PJe;

- Safety and health of workers and the Role of Ergonomics

- Quality of life at work

- Socially Sustainable Organizations

\section{METHOD OF RESEARCH}

Two different forms of literature review were used:

- Search for publications related to keywords: contributions of ergonomics in computerization processes; occupational safety and health, quality of life at work and the contribution of ergonomics for obtaining results of effectiveness in the provision of judicial services to citizens.

- Search for publications, in the period 2006-2014, through Google Scholar, whose key words included implementation of the electronic judicial process, ergonomics, and health and safety of judicial workers.

The existing practices in the implantation of the PC were observed in visits of the researcher to the working places.

Unstructured and open interviews were applied to managers of jurisdictional service units.

Readings of reports of the medical department of the analyzed institution were made, constituting a documentary research, which provided the necessary knowledge to reach the conclusions.

An analysis of the content of the articles and organization of the comparison between the theoretical foundation and the practices cited in the literature of implantation of the PJe was carried out.

\section{LITERATURE REVIEW}

Implementation of the Electronic Judicial Process (PJe)

From the twentieth century, human society entered a new historical level of production of wealth and values known as Information Revolution or Knowledge Revolution, in which information and knowledge began to play the central role in social activity. As a consequence, today, we are living at an electrifying pace online on the instantaneous internet, where the concepts of speed and mobility have been and continue to be modified at every instant. Society is governed by time and, for this reason, claims for brevity (Castro, 2016). In Brazil, the large-scale work with the use of the computer has increased over the last 30 years, thus changing definitely the relations of men with their work, leading them to reach a higher level (Guimarães, 2011).

According to Guasque and Freitas, 2013, these advances in technology that are consolidating through the alteration of interpersonal relations, leading to the explosion of the volume of information and the ease of access to them, besides the speed of communications, end up reaching justice. People's own way of life, increasingly immersed in technological advances, does not enable the judiciary to opt out of this evolution. In this context, the electronic process arises in Brazil, which is a pioneering country that is taking a step towards modernity, in the eagerness to follow the technological tendency of society and respond to its desires, providing access to justice according to the contemporary social reality. The authors cite the chair of the Information Technology Commission of the Brazilian Bar Association (OAB), which stated that there is no country in the world that has implemented the electronic process in the breadth that is being proposed in Brazil. There are examples, such as Spain, which has fully implemented electronic filing procedures for administrative procedures for tax jurisdiction; in Portugal, where electronic mail is used to practice certain procedural acts; in Switzerland, at the Conflict Mediation Center internet in the World Intellectual Property Organization and; in the United States where there is the PACER system that adopted the electronic process in the Federal Court; however, none of them will be as comprehensive as the Brazilian example and will not even have the volume of processes that will only be processed in digital format (Guasque et Freitas, 2013).

The computerization of judicial processes in Brazil began with the first norm dating from 1984, when Law No. 7,244 (Brasil, 1984) was promulgated, providing, in paragraph 3 of art. 14, the possibility of recording the acts performed at an investigation and trial hearing on a magnetic tape. This greatly modified the way of capturing and storing audiences, requiring the organisms a basic structuring in the area of informatics. 
A second noteworthy rule, to demonstrate that the legislator was already aware of modern communication technologies, is Law No. 8,245 (Brasil, 1991) of October 18, 1991, which, in its art. 58 subsection IV authorizes the summons and subpoena by fac simile. This possibility of practicing procedural acts via fac simile or other similar data transmission system, restricted to the acts of procedural communication, was extended to all procedural acts with the promulgation of Law 9,800 / 99 (Brasil, 1999), called Fax Law. The revolution provoked by the Fax Law, in fact, occurred with the opening of space for more progressive ideas of some operators of the Right that tried to use the Internet for the transmission of petitions, alleging that the e-mail is a data transmission system similar to the fax, which was initially rejected by the courts.

However, in 2001, through Law No. 10,259 (Brasil, 2001) of July 12,2001 , the use of electronic means for the practice and communication of procedural acts in federal special courts was expressly authorized when establishing, in $\S 2$ of art. 8, that "the courts may organize service of summons of the parties and reception of petitions by electronic means".

In 2006, another initiative of the legislator, in order to sanctify the possibility of practicing procedural acts with the use of electronic means, occurred with Law No. 11.280 / 2006 (Brasil, 2006). This law added a paragraph to the article 154 of the Brazilian Civil Procedure Code, ensuring the practice and official communication of procedural acts by electronic means, provided that the requirements of authenticity of authorship, integrity, legal validity and interoperability of the Brazilian Public Key Infrastructure - ICP-Brasil are met. It is noteworthy that not only the possibility of using electronic means was recognized, but also the requirements that must be met in order to ensure that the security of the information processed by computer networks is achieved.

Only in the end of 2006, the cycle of legal norms aimed at the computerization of the Brazilian civil process, seeking to comply with the precept of the reasonable length of time of the process was completed with the promulgation of Law 11,419 of December 19, 2006, which provides the computerization of the judicial process, amending Law No. 5,869, dated January 11, 1973 of the Code of Civil Procedure. An unprecedented phase of transition begins in the Judiciary, in which it is intended, based on the principle of the instrumentality of forms, to replace the physical process on paper with the stored computer memory accessible by means of the Internet.

Law No. 11,419 (Brasil, 2006) projects the Brazilian judiciary in a new era of the use of information and communication technology (ICT) with the objective of speeding up the process, as guaranteed by item LXXVIII of article 5 of the Federal Constitution of 1988 (Brasil, 1988), by ensuring to all, in the judicial and administrative spheres, the reasonable duration of the process and the means to guarantee the speed of its proceedings.

This consolidates a procedural reality that has gradually been implanted in the Brazilian legal-procedural system and which is progressively becoming part of the daily life of all those who deal directly or indirectly with the Judiciary.

\section{Contributions of ergonomics and Occupational Safety and Health for the effectiveness of the results of the juris- dictional services provided}

Although the relationship between work and health has been reported since Antiquity, it was only in the nineteenth century in Europe that the first formal approaches to this relationship began with the creation of Occupational Medicine. The International Labor Organization (ILO), created in 1919 , has dealt, since the beginning, with preventive norms for workers with the recommendation that occupational health services be created in companies. Since 1943, in Brazil, with the Consolidation of Labor Laws and with Law no. 6,514 , of 1977 , these services were foreseen and the environment in the space of the companies happened to be object of attention of the Engineering of Safety and the Occupational Hygiene. With the passage of time different manifestations of occupational sickness have been observed, from the musculoskeletal affections, culminating, in the present day, in the psychic repercussions Seligmann-Silva et al., 2010). It is essential for this scenario to be modified, that is, public policies for health promotion, prevention, care and professional rehabilitation must be implemented.

Santos et Mattos, in 2009, introduced their study citing some authors who defend the relationship between health and work, since they are part of the environment in which the worker carries out his activity and spends most of his life, in order to have his sustenance, satisfaction, valorization and achievement as a human being useful and provided with intellectual capacity. However, the dynamics of this relationship can be pathological, where the accelerated rhythm, competitiveness and excessive workday end up contributing to low self-esteem, fatigue, stress and sickness of the worker.

The authors also warn about occupational absenteeism as a major problem for both private and public companies, and absenteeism-disease is the cause that most distances workers. In their study, they concluded that the diseases that most distanced the group of workers analyzed were: mental diseases and diseases related to the musculoskeletal system and connective tissue. They conclude that strategies for the prevention and control of the problem is needed and the dialogue between stakeholders is urgent (Santos et Mattos, 2009). 
In this same line of reasoning, international authors also publish studies that raise concern in terms of the negative effects that work may have on workers' health; reflecting high rates of occupational accidents and illnesses, dissatisfaction with their work, turnover and low productivity (McCaughey et al, 2013).

To speak of safety and health of the worker is to refer to the science called Ergonomics. Although there are many definitions for Ergonomics, the aim is to remove from all such definitions the concern in terms of the adequacy of the tools and working environments to the workers and not the other way around.

According to Wilson et Corlett (2010), many authors try to divide Ergonomics as Physical, Cognitive, Social, but, in fact, its value is to aggregate all these aspects in a single one in order to meet the needs of users, of Systemic Ergonomics because it is the most integral, as it aggregates the physical, cognitive and social aspects.

The history of modern Ergonomics began in 1939-1945, with World War II. According to Chapanis (1996), it has a very close connection between the disciplines of engineering and medicine, taking into account anatomical, physiological and psychological factors, thus characterizing itself as a multidisciplinary science (Wilson et Corlett, 2010).

In most Ergonomics definitions, a list of criteria will be found so that the work, systems or products are comfortable, safe, effective and satisfactory. This gave an idea that only workers were benefited. However, it is assumed that the well-being of employees will be critical to their production, which also assists the employer. In this sense, cost-benefit analyzes are important here. In a broader context, the major goal of Ergonomics is to create a model where all interactions are taken into account, not only that relating to human factors with the machine. In this way, we would have the interactions of human factors with their work place and with the physical environment in which the work occurs as a whole; their social relations and the organization of work, taking into account the influence of external forces to work as well. Within this model, Ergonomics would evaluate the techniques needed to predict, investigate and develop each of the possible interactions between the individual-machine, individual-system (hardware or software), individual-environment, individual-employment, individual-individual, organization and individual world. The advantages of applying ergonomics must be contextualized in order to affect society's view of it and to be able to identify its value and place in the modern world. In this sense, financial, technological, legal, organizational, social, cultural and political factors must be addressed (Wilson et Corlett, 2010).
In addition, several examples are listed where project failure, sometimes leading to serious accidents with fatalities or, at times, high wasted costs, is due to human factors that were not considered. In this context, work systems that are developed without considering the end user also have a strong tendency to fail. For a system to work well, this user must be taken into consideration from the design and deployment phase to the operation. This methodology is defended by Ergonomics. Failure to apply ergonomics or its application improperly can increase the risks of discomfort, dissatisfaction and discomfort of the workforce. For the company, there could be a loss of competitiveness due to a decrease in production and the quality of its products. Attention is drawn to ergonomic products as well as to ergonomics in production, and this reasoning is not limited to work environments, but also to residential and even transport and leisure facilities. In all these situations, it becomes imperative to know the human factors that are involved in order to plan and operationalize companies, communities and society as a whole (Wilson et Corlett, 2010).

An example of the lack of management based on ergonomics was the beginning of computerization of banking jobs in the 1980s. On the one hand, it was considered a highly visible banking modernization policy and, on the other, after more than a decade, still with effects on the activities of poor subjects or poorly known. Ferreira (1997) draws attention to research in the field of ergonomics that points to two main factors that may be behind the origins of high error rates, rework, disinterest and rejection of banking operators: 1) cognitive capacity depletion and 2) the consequent collapse of operative strategy to treat and solve a certain task. Such shortcomings, according to this study, would be largely due to poor software / hardware design and technical-organizational requirements of the task, making users hostage to a logic that privileges the perfect functioning of the technical system to the detriment of their well-being.

The lack of Ergonomic Management leads, at the end of the line, to the psychic-physical illness of workers culminating in absenteeism due to illness, sequelae due to occupational or work diseases, needs for readaptations and even retirement due to disability, not to mention non-compliance with the Regulatory Standard 17 (Norma Regulamentadora 17 - NR 17) of the Ministry of Labor, which legislates on the obligation of undertakings to provide adequate working conditions for their workers. Without this adequacy, not only do we have a chance of a functional loss of workers with personal compromise for the rest of their lives, as high costs for social security, as well as productivity impaired for the company that loses its intellectual capital and, therefore, its competitiveness (Santos et Mattos, 2009). 
Brazilian Journal of Operations \& Production Management

Volume 15, Número 1, 2018, pp. 127-136

DOI: 10.14488/BJOPM.2018.v15.n1.a11

\section{ANALYSIS AND DISCUSSION OF RESULTS}

From the literature review and the documentary analysis it was possible to verify that the scientific literature has evidences of the repercussions of the implantation of the Electronic Judicial Process on the health of the justice workers. Knowing that the PC is an innovative path and without retreat, it is expected that reflections regarding the identification of improvements not only for external users, but also for internal users, will be prioritized, trying to avoid negative experiences already experienced by other groups of workers (Guimarães et al, 2011; Ferreira, 1997).

By having relevant action in society, as the guarantor of rights, the Brazilian Judiciary powers to work with effectiveness.

It is necessary to continuously improve public management in organizations that deal daily with the problems of society.

It can be observed that Brazilian judicial organizations have implemented initiatives in this direction. According to Bezerra (2014) and Ferreira et al. (2009), the greater ability to obtain effective results in the execution of the work requires the constant learning and investment in projects that enable better quality of life in the work of servers.

In this sense, some initiatives can be taken into account for this improvement, such as the use of Information Technology (IT) resources, investment in human capacity building for all hierarchical levels, thus improving the transparency of Justice. For example, with the publication of Law No. 11,419 of December 19, 2006, the Brazilian Judiciary took an irreversible course: the implementation of the Electronic Judicial Process (PJe).

In this sense, the implantation of the PJe seems to be a solution, since there is a great acceleration in the processing time of the judicial processes, mainly, by the reduction of the "dead time" of the process, that is, of those periods in which the process stands between one judicial act and another (Santos et Reis, 2011).

However, parallel to the context of society's dissatisfaction with the Brazilian Judicial Public Institutions due to the inability to meet the increased demand for justice; in the field of Occupational Health, the growing sickness of servers of several institutions is evidenced (Bragatto et al., 2010).

The central concept of a Total Quality Management System, through the use of the "PDCA" cycle (Plan, Do, Check and Action), every process should be planned in order to obtain substantial results and the necessary reflections on improvements must be maintained in order to ensure their success (Fonseca et Miyake, 2006). Thus, the PJe ("Judicial Power Eletronic"), as an innovative process and with the objective of achieving substantial results, cannot fail to consider these premises.

Following this reasoning, in 2018, after almost a decade of the beginning of the implantation of the PJe, the main concerns regarding the possible improvements in the operationalization of the PJe regards not only the need to increase speed, but also the quality of the judicial performance, besides the investment in resources that promotes the Quality of Work Life, composed of several dimensions, being the most evident: the guarantee of the safety and health of servers and the Ergonomics that consists in the correlation of the relations between health and work and the performance of the organization (Pereira, 2003).

Opportunities for Improvement in the implantation of the PJe regarding Quality of Life and protection against ergonomic and occupational safety risks

When referring to the welfare of workers, to occupational safety and health, and to quality of life at work, there is an insertion in the area of the theme that responds to the demands: Ergonomics. According to the scientific and technical literature and the observations in the field, this study proposes to reflect on the possible contributions that the introduction of the pro-ergonomic culture can bring to the implantation of the PC, providing gains in all its aspects, from the QVT of the workers, to the increase in terms of productivity; thus, one can potentially have the speed and quality of the jurisdictional provision of the Brazilian Courts of Justice.

\section{Recognition of the need to implement an ergonomic culture in the Judiciary: A Documentary Research}

In addition to the studies listed in Table 1, some actions of Brazilian courts have been showing their concern in terms of the need to introduce the pro-ergonomic culture in their work environment to promote the well-being of their workers. An example is the Minas Gerais Court of Justice (TJMG), which through its strategic project included the theme "Health and Integration". In its scope, it makes clear the need to meet the appropriate infrastructure and management requirements for administrative and judicial activities in order to provide healthy and inclusive environments. In this aspect, it seeks to work with themes focused on ergonomics, functional readjustment and inclusion of people with disabilities. In this way, these actions are in line with the mission, vision, future and institutional values observed in the current norms and provision of the National Justice Council (CNJ), especially Recommendation No. 27 of 2009, published in the DOU, section $1,10 / 25 / 2010$, page 107 , and 
Table 1. Comparison between practices identified in the PC and Ergonomics Light Improvement Opportunities

\begin{tabular}{|c|c|c|c|c|}
\hline Author & Title & $\begin{array}{l}\text { Newspaper / } \\
\text { University }\end{array}$ & Observed Practice & Improvement opportunity \\
\hline $\begin{array}{l}\text { Cândido } \\
\text { Alfredo } \\
\text { Silva Leal } \\
\text { Júnior }\end{array}$ & $\begin{array}{l}\text { Electronic } \\
\text { process and } \\
\text { health of } \\
\text { federal mag- } \\
\text { istrates in } \\
\text { Rio Grande } \\
\text { do Sul }\end{array}$ & $\begin{array}{l}\text { Association } \\
\text { of Federal } \\
\text { Judges of RGS } \\
\text { - AJUFERGS - } \\
\text { Research on } \\
\text { electronic pro- } \\
\text { cess and health } \\
\text { of federal mag- } \\
\text { istrates of Rio } \\
\text { Grande do Sul, } \\
\text { Porto Alegre, } \\
\text { June } 2011 .\end{array}$ & $\begin{array}{l}\text { Research carried out with Federal Magistrates } \\
\text { of the RGS, Associates of Ajufergs, about their } \\
\text { perception regarding health conditions and the } \\
\text { computer resources made available for the Ju- } \\
\text { risdictional provision from the implementation } \\
\text { of the electronic process in all the judicial units } \\
\text { of the 4th Region. Data was collected between } \\
\text { May and June } 2011 \text { due to many complaints } \\
\text { that the Association received about this new } \\
\text { work process. }\end{array}$ & $\begin{array}{l}\text { Suggests dissemination of the re- } \\
\text { sults in order to hold seminars with } \\
\text { the federal judges of the 4th Region } \\
\text { to discuss issues related to health } \\
\text { and the electronic process (disease } \\
\text { prevention, occupational medicine, } \\
\text { ergonomics, usability) }\end{array}$ \\
\hline $\begin{array}{l}\text { Claudete } \\
\text { Magda } \\
\text { Calderan } \\
\text { Caldas e } \\
\text { Marcelle } \\
\text { Cardoso } \\
\text { Louzada }\end{array}$ & $\begin{array}{l}\text { The effects } \\
\text { of the } \\
\text { Electronic } \\
\text { Judicial } \\
\text { Process on } \\
\text { the working } \\
\text { conditions of } \\
\text { procedural } \\
\text { actors }\end{array}$ & $\begin{array}{l}\text { International } \\
\text { Congress on Law } \\
\text { and Contem- } \\
\text { poraneity, June } \\
\text { 2013, Santa } \\
\text { Maria / RS }\end{array}$ & $\begin{array}{l}\text { Review of the literature on the reflexes of the } \\
\text { transition from physical judicial process to the } \\
\text { electronic version on the working conditions } \\
\text { of those who operate the system (lawyers, } \\
\text { magistrates, prosecutors, experts, officials and } \\
\text { / or judicial servants). }\end{array}$ & $\begin{array}{l}\text { Suggestion of preventive measures } \\
\text { such as reduction of workload, } \\
\text { inclusion of mandatory intervals } \\
\text { in the working day, relaxing work } \\
\text { activities, physiotherapy and } \\
\text { follow-up, leading to a change of } \\
\text { the Judiciary that can have the } \\
\text { electronic procedural system as a } \\
\text { positive and effective tool. }\end{array}$ \\
\hline $\begin{array}{l}\text { Liana Laut- } \\
\text { ert, Álvaro } \\
\text { Roberto } \\
\text { Crespo } \\
\text { Merlo, Ger- } \\
\text { aldo de } \\
\text { Azevedo e } \\
\text { Souza Filho } \\
\text { et al. }\end{array}$ & $\begin{array}{l}\text { Repercus- } \\
\text { sions of the } \\
\text { Virtual Work } \\
\text { of the Fed- } \\
\text { eral Special } \\
\text { Court of Rio } \\
\text { Grande do } \\
\text { Sul on Work- } \\
\text { er's Health }\end{array}$ & $\begin{array}{l}\text { Report of the } \\
\text { Interdisciplin- } \\
\text { ary Group of } \\
\text { Occupational } \\
\text { Health - Federal } \\
\text { University of Rio } \\
\text { Grande do Sul } \\
\text { - Porto Alegre, } \\
2010\end{array}$ & $\begin{array}{l}\text { The investigation took place at the request of } \\
\text { the employees of the Federal Special Court } \\
\text { (JEF) of the State of Rio Grande do Sul to its } \\
\text { Union (SINTRAJUF) for complaints arising from } \\
\text { the negative repercussions that the implan- } \\
\text { tation of new work technologies - use of the } \\
\text { system known as Electronic Process of Federal } \\
\text { Court (e-proc) - has caused his health by mod- } \\
\text { ifying the organization of work, demand and, } \\
\text { thus, control of activity. }\end{array}$ & $\begin{array}{l}\text { The following recommendations } \\
\text { were made: Reduction of the work- } \\
\text { load, Training and support for the } \\
\text { use of technological resources and } \\
\text { Continuing education. }\end{array}$ \\
\hline $\begin{array}{l}\text { Marcelo } \\
\text { Pereira } \\
\text { Cruvinel }\end{array}$ & $\begin{array}{l}\text { The Innova- } \\
\text { tion of the } \\
\text { computer- } \\
\text { ized judicial } \\
\text { process in } \\
\text { the STJ }\end{array}$ & $\begin{array}{l}\text { Monograph } \\
\text { presented to the } \\
\text { Administration } \\
\text { Department } \\
\text { of the Faculty } \\
\text { of Economics, } \\
\text { Administration, } \\
\text { Accounting and } \\
\text { Information } \\
\text { Science and } \\
\text { Documentation } \\
\text { (FACE), } \\
\text { Brasília - DF, } \\
2009 .\end{array}$ & $\begin{array}{l}\text { This study conducts an exploratory research } \\
\text { in order to identify and characterize the main } \\
\text { requirements regarding the innovation of the } \\
\text { electronic process in the organizational context } \\
\text { of the STJ. }\end{array}$ & $\begin{array}{l}\text { One of its conclusions is that fed- } \\
\text { eral resources must be made avail- } \\
\text { able so that the developed product } \\
\text { (electronic process) is carried out in } \\
\text { a harmonious and progressive way. }\end{array}$ \\
\hline
\end{tabular}




\begin{tabular}{|c|c|c|c|c|}
\hline Author & Title & $\begin{array}{l}\text { Newspaper / } \\
\text { University }\end{array}$ & Observed Practice & Improvement opportunity \\
\hline $\begin{array}{l}\text { Adriana } \\
\text { Kátia } \\
\text { Ternes Mo- } \\
\text { resco, Ari } \\
\text { Dorvalino } \\
\text { Shurhauls }\end{array}$ & $\begin{array}{l}\text { The reflexes } \\
\text { of automa- } \\
\text { tion in the } \\
\text { organization } \\
\text { of the work } \\
\text { of the Santa } \\
\text { Catarina } \\
\text { judiciary }\end{array}$ & $\begin{array}{l}\text { Collection Orga- } \\
\text { nizational Man- } \\
\text { agement and } \\
\text { Technology in } \\
\text { Human Resourc- } \\
\text { es: Outstanding } \\
\text { topics in the } \\
\text { management of } \\
\text { the judiciary in } \\
\text { Santa Catarina, } \\
\text { volume 1: } \\
\text { P. 39-66 }\end{array}$ & $\begin{array}{l}\text { The theoretical basis of this study is based } \\
\text { on the reflection on work and ergonomics, } \\
\text { emphasizing that the quality of life of the } \\
\text { individual is influenced by the quality of all } \\
\text { his functional life and the space that the work } \\
\text { occupies in his existence, drawing attention to } \\
\text { the application of the technology power in the } \\
\text { judiciary. }\end{array}$ & $\begin{array}{l}\text { It concludes that the benefits of im- } \\
\text { plementing the virtual process are } \\
\text { undeniable. However, it considers } \\
\text { that the instruments and proce- } \\
\text { dural steps need to be completely } \\
\text { remodeled in order to extract ben- } \\
\text { efits that will enable true automa- } \\
\text { tion and consequent rationalization } \\
\text { of procedures and resources. } \\
\text { It draws attention to the need } \\
\text { to prepare the server to act in } \\
\text { this new context, noting that the } \\
\text { employees within an organization } \\
\text { are human beings, and cannot be } \\
\text { considered only resources that } \\
\text { the organization uses to reach its } \\
\text { objectives. It also emphasizes that } \\
\text { at a time when new horizons open } \\
\text { up, it is time for organizations to as- } \\
\text { sume their social role that is before } \\
\text { the community. }\end{array}$ \\
\hline $\begin{array}{l}\text { Fernando } \\
\text { Reis de } \\
\text { Abreu, } \\
\text { César } \\
\text { Marques } \\
\text { Carvalho, } \\
\text { Alexandre } \\
\text { Teixeira de } \\
\text { Freitas Bas- } \\
\text { tos Cunha, } \\
\text { Raquel de } \\
\text { Oliveira } \\
\text { Maciel }\end{array}$ & $\begin{array}{l}\text { Implemen- } \\
\text { tation of the } \\
\text { Electronic } \\
\text { Judicial } \\
\text { Process in } \\
\text { the Regional } \\
\text { Labor Court } \\
\text { of the First } \\
\text { Region, }\end{array}$ & $\begin{array}{l}\text { Revista Eletrôni- } \\
\text { ca, year 3- n.3, } \\
\text { Judicial School } \\
\text { - TRT - 1st. } \\
\text { Region: p. 12, } \\
\text { 2013. }\end{array}$ & $\begin{array}{l}\text { In the aspect of Change Management, alert to } \\
\text { the health of internal users, who stop lowering } \\
\text { to pick up processes or to load heavy volumes } \\
\text { of cars to maintain a permanent work with the } \\
\text { electronic process that can also cause health } \\
\text { problems by permanent typing, reading on } \\
\text { screen, and without walking as well. }\end{array}$ & $\begin{array}{l}\text { They consider it essential that the } \\
\text { operators of the electronic process } \\
\text { system are able to interrupt the } \\
\text { pre-established work period and } \\
\text { perform quick exercises during the } \\
\text { working day. In addition, they draw } \\
\text { attention to moderate access to the } \\
\text { system, establishing specific work } \\
\text { schedules, exercises and rest. }\end{array}$ \\
\hline
\end{tabular}

in DJ-e No. 15/2010, 1/25/2010, page 2-4. In compliance with this objective, Joint Ordinance No. 220/2011, which instituted the Ergonomics Committee of the TJMG, was published in the DJE on July 21, 2011.

At the Congress of Health of the Judiciary held by the Center for Judicial Studies of the Federal Justice Council (CEJ / CJF) and the Superior Court of Justice (STJ) in November 2013, Brasília, the theme ergonomics was also approached by a specialist in Social Psychology, Labor and Organizations, Polyanna Peres. She presented one of the concepts of Ergonomics, remembering that external factors impact on the work and the way the workers stand in their day to day, raising the question of technological developments. She stressed that it is necessary to know who the worker is in order to promote policies that meet his needs and also of the organization to which he belongs.

Also in this context, according to the goals of the CNJ for 2013, those of numbers nine and ten recommend care with the well-being of the Labor Justice workers as the implementation of the Medical Occupational Health Control Program (PCMSO) and Environmental Risk Program (PPRA) in at least $65 \%$ of the judicial and administrative units and the accomplishment of ergonomic adjustment in $20 \%$ of the judicial units of 1 st and 2 nd degree, respectively.

At the meeting of the Strategic Planning Steering Committee of the Federal Justice on March 26 and 27, 2014, in order to prepare for the VIII National Judiciary Meeting, the macro challenges of this planning for the next six years (2015 to 2020) were discussed. Among the core macro-challenges, federal Judge Kelly Costa spoke of those selected, involving "Improving People Management", "Improving Infrastructure and Governance of Information Technology", "Improving Cost Management", and "The Institution of Judicial Governance". In order to follow up on these themes, the committee has adopted three indicators of improvements 
in the area of people management - one of them aims to increase the index of magistrates and servants who adhere to the periodic health examination; another one aims to increase the satisfaction index of servants and magistrates and; the last of them intends to keep the index of absences to work below $3 \%$.

According to the judge, in order to gather information on the satisfaction index, an organizational climate survey will be created to be organized by the CJF, which will adopt a methodology that will address several issues, among them: intensity of the psychic and physical workload; speed, pace and breaks at work; recognition; degree of autonomy; content of activities performed; relationship with managers and colleagues; access to information and; satisfaction in terms of working conditions related to physical facilities, material resources, furniture and the ergonomics of the station. He also said: "We are concerned about the health of our servants and magistrates, within the scope of the entire Federal Court. Unfortunately, we do not yet have consistent policy around periodic health examinations for civil servants and magistrates and, although it is common practice in the STJ, this prioritization within TRFs does not yet exist".

\section{CONCLUSIONS AND SUGGESTIONS FOR FURTHER RESEARCH}

The purpose of this research was to search and evaluate comparatively the contents of scientific publications with the practices of implantation of the PC in the Brazilian Courts of Justice and its repercussions on the health of its internal users and the opportunities of improvements in its development through the quality of life in the work with the application of Ergonomics.

The public service, and particularly Justice, emerges as a field of research and intervention for Ergonomics in the face of various phenomena such as intensification of work, degradation of the Public Service, management models and public organization and lack of more robust public policies that protect the servers.

In view of this scenario, and in the face of everything that has been exposed through the literature review on pertinent topics and on the implantation of the PC itself, it is suggested a proposal of change where the Organizations commit themselves to a Management based on Quality, Health and Worker Safety, in the protection of the environment, thus becoming, in fact, Socially Sustainable Organizations.

It is indisputable that this moment is unique in the Judiciary, in the age of technology, when an innovative work process with the expectation of high effectiveness is seen as an option to offer society quick, high quality and economi- cal judicial services. However, Managers can no longer deny that all its benefits will come to the fore if the commitment to those who directly participate in it, the Judiciary workers, is considered. Therefore, the beginning of this new work process should be based on the reflection on its implementation, in order to consider a socially sustainable management.

In the last eight years, after the publication of Law no. $1419 / 2006$, according to the literature review, what can be perceived is that the PJe is being implanted with structural and conceptual errors regarding modern management systems, since the Judiciary is putting all its focus on celerity and economics of the PJe to the detriment of its quality and the health and safety of its workers.

However, due to the fact that they still need more emphasis, the attention paid to cultural aspects in the creation of knowledge in judicial organizations deserves to be highlighted. It is understood that the process of organizational learning is not merely the transmission of information, but the possibility of building new values, attitudes and world views.

There is no way to think of increasing capacity for action without creating a context conducive to learning. In addition, one cannot think of new models without reflecting on them and constructing something from this reflection.

In the introduction of new management practices for public organizations, goals and indicators have been created; however, it seems that this is not enough for a better performance in society. Another point to note concerns our political culture. Traditional bureaucratic instruments, valuing control and coercion, inhibit people's autonomy.

It is necessary that the management of public institutions that make up the Brazilian judiciary adopt internal social responsibility, including management tools and knowledge in ergonomics.

Quality, according to the contemporary concepts, recognized by the academy and by the organizational practices of the market, represents sustainability, according to paradigms that allow effective results to the PC. For this purpose, field surveys should be developed in order to better understand the opportunities for improvement in the knowledge of Ergonomics in the implantation of the PJe in the various states of Brazil where the PJ is implemented.

\section{REFERENCES}

Castro, A. A. (2016), "O documento eletrônico e a assinatura digital: uma visão geral", disponível em: http://www.aldemario.adv.br/doceleassdig.htm (acesso em: 21 abr. 2014). 
Costa Júnior, O. M. (2015), “O processo judicial eletrônico na Justiça do trabalho: as conquistas e os desafios dessa nova ferramenta tecnológica", Revista do Tribunal Regional do Trabalho da 10ạ Região [recurso eletrônico], Vol. 19, No. 20, pp. 123-36.

Ferreira, M. C. et al. (2009), Gestão de Qualidade de Vida no Trabalho (QVT) no serviço público federal: o descompasso entre problemas e práticas gerenciais, Psicologia: Teoria e Pesquisa, Vol. 25, No. 3, pp. 319-27, available from: http:// www.scielo.br/scielo.php?script=sci_arttext\&pid=S0102-37722009000300005\&lng=en\&nrm=iso (Access: 05 Jan 2018).

Fonseca, A.V.M.; Miyake, D.I. (2006), “Uma análise sobre o Ciclo PDCA como um Método para solução de problemas da qualidade", in: XXVI ENEGEP - ABEPRO, Fortaleza, Ceará, 2006.

Guasque, B.; Freitas, C.O.A. (2013), "Política judiciário e processo eletrônico: eficácia socioeconômica", Direito e Justiça, Vol.39, No.1, pp.58-68.

Guérin, F. et al. (2001), Compreender o Trabalho para Transformá-lo. A Prática da Ergonomia, 1st ed., Editora Blucher, São Paulo.

Guimarães, B.M. (2011), "Análise da carga de trabalho de analistas de sistemas e dos distúrbios osteomusculares", Fisioterapia em Movimento, Vol. 24, No. 1, pp. 115-24.

Maccaughey, D. et al. (2013), "The negative effects of workplace injury and illness on workplace safety climate perceptions and health care worker outcomes", Safety Science, Vol. 51, pp. 138-47.
Moura, R. J. M. (2014), "Efetividade da Prestação Jurisdicional com a implantação do Processo Judicial Eletrônico na Justiça do Trabalho", disponível em: http://hdl.handle. net/123456789/1110 (acesso em: 06 jan. 2018).

Pereira, C. (2003), Programas de Prevenção a Saúde do Trabalhador no Serviço Público - O caso do Tribunal de Justiça do Estado de Minas Gerais, Dissertação de Mestrado em Engenharia de Produção, Universidade Federal de Santa Catarina, Florianópolis, SC, 2003.

Rothberg, D. (2010), "Contribuições a uma teoria da democracia digital como suporte à formulação de políticas públicas", Revista Iberoamericana de Ciencia Tecnología y Sociedad, Vol. 5, No. 14, pp. 69-87, disponible en: http:// www.scielo.org.ar/scielo.php?script=sci_arttext\&pid=S1850-00132010000100004\&lng=es\&nrm=iso (accedido em: 06 Enero 2018).

Santos, M. A.; Reis, S. C. (2011), "Breves reflexões sobre o Processo Eletrônico no TRT da 13a Região", in: Âmbito Jurídico, Rio Grande, Vol. XIV, No. 92, disponível em: http://ambitojuridico.com.br/site/?n_link=revista_artigos_leitura\&artigo_ $\mathrm{id}=10361$ \&revista_caderno=21(acesso em: 7 abr. 2014).

Seligmann-Silva, E. et al (2010), "Saúde do Trabalhador no início do século XI", Revista Brasileira de Saúde Ocupacional, Vol.35, No.122, pp.15-186.

Tavares, D. S. (2003), O sofrimento no trabalho entre servidores públicos: uma análise psicossocial do contexto de trabalho em um Tribunal Judiciário Federal, Dissertação de Mestrado em Saúde Ambiental, Faculdade de Saúde Pública, Universidade de São Paulo, São Paulo, SP, 2003. doi:10.11606/D.6.2003.tde-20032004-083408.

Received: Jan 10, 2018

Approved: Jan 10, 2018

DOI: 10.14488/BJOPM.2018.v15.n1.a11

How to cite: Yparraguirre, I. R. (2018), "The contribution of ergonomics to the effectiveness of the public service: analysis of the implementation of the Electronic Judicial Process (PJe)", Brazilian Journal of Operations \& Production Management, Vol. 15, No. 1, pp. 127-136, available from: https://bjopm.emnuvens.com.br/bjopm/ article/view/430 (access year month day). 